\title{
Etos Kerja Penerima Bantuan Dana Bergulir PNPM Mandiri Kelurahan Latuppa Kecamatan Mungkajang Kota Palopo
}

\author{
Tenri Jaya ${ }^{1}$, Lilis Suryani ${ }^{2}$ \\ ${ }^{12}$ Institut Agama Islam Negeri Palopo, ${ }^{1}$ Dosen Prodi Sosiologi Agama FUAD \\ ${ }^{2}$ Dosen Prodi PGMI FTIK \\ ${ }^{1}$ Email: Tenri Jaya@Iainpalopo.ac.id \\ ${ }^{2}$ Email: Lilis_Suryani@iainpalopo.ac.id
}

(Received: Maret 2019; Reviewed: Maret 2019; Accepted: April 2019; Published: 01 Mei 2019)

Ini adalah artikel dengan akses terbuka dibawah license CC BY-NC-4.0 (C2019 oleh penulis (https://creativecommons.org/licenses/by-nc/4.0/ ) .

\begin{abstract}
This study aims to determine: 1) the factors that influence the high work ethic of PNPM Mandiri revolving fund recipients. 2) analyzing the application of work processes can stimulate the work ethic of recipients of PNPM Mandiri revolving funds. This research is a qualitative research. Retrieval of data in research using in-depth interviews, and documentation, then analyzed using descriptive qualitative analysis techniques. The results showed that: 1) Recipients of PNPM Mandiri revolving fund assistance have a high work ethic because it is influenced by several things, as follows: (a) The existence of interpersonal expertise, (b) The existence of high initiative; (c) The existence of reliability values, (d) The existence of empowerment and learning, (e) The existence of internal factors (age, sex, religion, and motivation) external factors (cultural factors, geographical environmental conditions and economic structure), and several other factors that researchers find in the field, such as needs, obligations and responsibilities, and group factors. 2) The process of implementing the PNPM Mandiri revolving fund aid work program that stimulates work ethics is (a) revitalizing and learning social moral values; (b) building critical awareness of the community to participate directly in the implementation of the PNPM Mandiri revolving fund assistance program, which starts from the process of problem identification, planning, implementation, supervision to program evaluation; (c) learning to group in facing and solving common problems.
\end{abstract}

Keywords: Work Ethic; PNPM Mandiri

\section{ABSTRAK}

Penelitian ini bertujuan untuk mengetahui: 1) faktor-faktor yang mempengaruhi tingginya etos kerja penerima bantuan dana bergulir PNPM Mandiri. 2) menganalisis penerapan program kerja berproses dapat menstimulasi etos kerja penerima bantuan dana bergulir PNPM Mandiri. Penelitian ini merupakan penelitian kualitatif. Pengambilan data dalam penelitian menggunakan wawancara mendalam, dan dokumentasi, selanjutnya dianalisis menggunakan teknik analisis deskriptif kualitatif. Hasil penelitian menunjukkan bahwa: 1) Penerima bantuan dana bergulir PNPM Mandiri memiliki etos kerja tinggi karena dipengaruhi oleh 
beberapa hal yakni sebagai berikut: (a) Adanya keahlian interpersonal;(b) Adanya inisiatif tinggi; (c) Adanya nilai-nilai kehandalan;(d) Adanya pemberdayaan dan pembelajaran;(e) Adanya faktor internal (faktor usia, jenis kelamin, agama, dan motivasi) faktor eksternal (faktor budaya, kondisi lingkungan geografis dan struktur ekonomi), dan beberapa faktor lain yang peneliti temukan dilapangan, seperti faktor kebutuhan, kewajiban dan tanggung jawa, serta faktor kelompok. 2) Proses penerapan program kerja bantuan dana bergulir PNPM Mandiri yang mengstimulasi etor kerja adalah (a) revitalisasi dan pembelajaran nilai-nilai moral kemasyarakatan; (b) membangun kesadaran kritis masyarakat untuk ikut berpartisipasi secara langsung dalam pelaksanaan program kerja bantuan dana bergulir PNPM Mandiri yakni mulai dari proses identifikasi masalah, perencanaan, pelaksanaan, pengawasan sampai pada evaluasi program; (c) pembelajaran untuk berkelompok dalam menghadapi dan menyelesaikan masalah bersama.

Kata Kunci: Etos Kerja; PNPM Mandiri

\section{PENDAHULUAN}

Dalam era globalisasi, persaingan kerja yang semakin meningkat setiap manusia untuk menguasai keahlian dan kemampuan tertentu. Untuk dapat menjawab tantangan ini diperlukan adanya dedikasi, kerja keras dan kejujuran dalam bekerja. Perusahaan besar dan terkenal telah membuktikan bahwa etos kerja yang militan menjadi salah satu dampak keberhasilan perusahaan. Etos kerja seseorang erat kaitannya dengan kepribadian, perilaku, dan karakter. Setiap orang memiliki internal being yang merumuskan siapa dia, selanjutnya internal being menetapkan respon, atau reaksi terhadap tuntutan eksternal dunia kerja menetapkan etos kerja seseorang. Siregar dalam Sinamon (2005).

Tasmara (2002: 25) dalam Prabowo (2009) mengemukakan bahwa etos kerja merupakan totalitas kepribasian diri serta caranya mengekspresikan, memandang, meyakini, dan memberikan makna, adea sesuatu yang mendorong dirinya untuk bertindak dan meraih amal yang optimal sehingga pola hubungan antara manusia dengan dirinya dan antara manusia dengan makhluk lainnya dapat terjalin dengan baik. Sesuatu yang mendorong tersebut tak lain adalah kebutuhan.

Program bantuan dana bergulir PNPM Mandiri merupakan bagian program Nasional Pemberdayaan Masyarakat (PNPM) mandiri dalam bidang ekonomi. Dalam program ini, pemerintah menyediakan dana pinjaman bagi masyarakat miskin untuk dijadikan modal usaha. Bantuan dana bergulir PNPM mandiri dapat diakses melalui KSM (Kelompok Swadaya masyarakat). Bantuan Dana Bergulir PNPM Mandiri, sebagai dana stimulan untuk memulai suatu usaha atau mengembangkan usaha yang sudah digeluti. Penerapan program bantuan dana bergulir PNPM Mandiri menggunakan pendekatan partisipatif dengan konsep pemberdayaan dan pembelajaran kritis masyarakat. Terminologi partisipatif sangat melekat dengan terminologi pemberdayaan. Partisipasi masyarakat diartikan sebagai keterlibatan warga masyarakat dalam proses pelaksanaan program kerja bantuan dana bergulir PNPM Mandiri.

Pemberdayaan masyarakat adalah sebuah konsep pembangunan ekonomi yang merangkum nilai-nilai sosial. Konsep ini mencerminkan paradigma baru pembangunan, yakni yang bersifat "peoplecentered,participatory, empowering, and sustainable"Chambers (dalam Tim PNPM Mandiri, 2007). Konsep ini lebih luas bukan hanya semata-mata memenuhi kebutuhan dasar (basic needs) akan tetapi juga menyediakan mekanisme untuk mencegah proses pemiskinan lebih lanjut (safety net. Pemberdayaan dan pembelajaran yang dilakukan oleh tim pelaksana program bantuan dana bergulir PNPM Mandiri meliputi pembelajaran penerapan nilai - nilai moral manusia dan nilai - nilai kemasyarakatan dalam bekerja dan menjalankan usah, pembelajaran 
mengidentifikasi kebutuhan semdiri dan masalah yang dihadapi, mencari jalan keluar dari masalah tersebut, serta mengembangkan potensi - potensi diri sehingga masyarakat miskin tersebut dapat memiliki kemampuan, kecakapan, kualitas dan motifasi dalam berusaha (bekerja) sehingga pada akhirnya melahirkan keyakinan, pandangan, sikap menghargai kerja sebagai sesuatu yang berharga dan bernilai bagi kehidupan. Data BPS menunjukkan bahwa program PNPM Mandiri cukup signifikan mengatasi jumlah masyarakat miskin di Indonesia.

Data penurunan tingkat kemiskinan sejak mulai diterapkan program PNPM Mandiri yakni: tahun 2007angka kemiskinan menunjukkan 16,58 \%, tahun 2008 angka kemiskinan turun menjasi $15,42 \%$, tahun 2009 angka kemiskinan menjasi $14,15 \%$, tahun 2010 angka kemiskinan turun menjadi $13,33 \%$, tahun 2011 angka kemiskinan turun menjadi 11,5\%-12,5\%. Data tersebut menunjukkan setiap tahun angka kemiskinan berkurang sekitar 1,2\%. Dan jika program ini terus berlanjut diperkirakan tahun 2013 penduduk miskin Indonesia tinggal sekitar $5 \%$. Sujana Royat mengatakan $60 \%$ kesejahteraan masyarakat meningkat oleh program pemberdayaan PNPM Mandiri.

Terkhusus di kelurahan Latuppa

Kecamatan Mungkajang Kota palopo, penerima manfaat dana bantuan bergulir PNPM Mandiri mulai tahun 2008 sebanyak 8 KSM (Kelompok Swadaya Masyarakat) dan tahun 2011 mencapai $60 \mathrm{KSM}$. Ini berarti bahwa adanya peningkatan jumlah KSM yang cukup signfikan. Peningkatan jumlah KSM penerima bantuan dana bergulir PNPM Mandiri tidak lain atas keberhasilan mereka dalam mengelolah bantuan dana pinjaman bergulir PNPM Mandiri tersebut. Keberhasilan ini mampu dicapai oleh para penerima bantuan dana bergulir PNPM mandiri dikelurahan Latuppa atas keuletan, ketekunan, dan etos kerja mereka dalam mengelolah usaha atau bisnisnya.

Kajian mengenai PNPM Mandiri telah pernah dikaji oleh beberapa ilmuwan, diantaranya: tahun 2007 Marnia Nes menulis tentang daur program pembangunan partisifatif PNPM Mandiri, pada tahun 2011 Wirawan membahas tentang evaluasi PNPM Mandiri pedesaan. Namun Khusus yang meneliti tentang etos kerja penerima bantuan dana bergulir PNPM Mandiri, inilah kajian yang pertama.

\section{A. Aspek-Aspek Etos Kerja}

Novliadi 2009 mengatakan bahwa ada beberapa aspek yang meleka pada diri manusia yang menjadi karakteristik etos kerja, yaitu " keahlian interpersonal, inisiatif, dan kehandalan".

1. Keahlian Interpersonal

Keahlian Interpersonal adalah aspek yang berkaitan dengan hubungan kerja dengan orang lain atau bagaimana pekerja berhubungan dengan pekerja lain dis lingkungan kerjanya. Keahlian Interpersonal meliputi kebiasaan, sikap, cara, penampilan dan perilaku yang digunakan individu saat berada disekitar orang lain serta mempengaruhi bagaimana individu berinteraksi dengan orang lain. Indikator yang digunakan untuk mengetahui Keahlian Interpersonal seorang pekerja meliputi karakteristik pribadi yang dapat memfasilitasi terbentuknya hubungan interpersonal yang baik dan dapat memberikan kontribusi dalam performansi kerja seseorang, dimana kerja sama merupakan suatu hal yang sangat penting. Terdapat 17 sifat yang dapat menggambarkan Keahlian Interpersonal seorang pekerja yaitu : sikap sopan, sikap bersahabat, sikap gembira, sikap penuh perhatian, sikap menyenangkan, kerjasama, menolong, disenangi, tekun,loyal, rapi, sabar, apresiatif, kerja keras, rendah hati, emosi yang stabil, dank eras kemauan.

2. Inisiatif

Inisiatif merupakan karakteristik yang dapat memfasilitasi seseorang agar terdorong untuk lebih meningkatkan kinerjanya dan tidak langsung merasa puas dengan kinerja yang biasa. Aspek ini sering dihubungkan dengan situasi di tempat kerja yang tidak lancar. Hal- hal seperti penundaan pekerjaan, hasil kerja yang buruk, kehilangan kesempatan karena tidak dimanfaatkan dengan baik dan kehilangan pekerjaan, dapat muncul jika individu tidak memiliki inisiatif dalam bekerja. Terdapat 16 sifat yang dapat menggambarkan inisiatif seorang pekerja 
yaitu: sikap cerdik, produktif, banyak ide, berinisiatif, ambisius, efisien, efektfi, antusias, dedikasi, daya tahan kerja, akurat, teliti, mandiri ,mampu beradaptasi, gigih, dan teratur.

3. Kehandalan

Kehandalan adalah aspek yang berhubungan dengan adanya harapan terhadap hasil kerja seorang pekerja dan merupakan suatu perjanjian implicit pekerja untuk melakukan beberapa fungsi dalam kerja. Seorang pekerja diharapkan dapat memuaskan harapan minimum perusahaan, tanpa perlu terlalu berlebihan sehingga melakukan pekerjaan yang bukan tugasnya. Aspek ini merupakansalah satu hal yang sangat diinginkan oleh pihak perusahaan terhadap pekerjanya. Terdapat 7 sifat yang dapat menggambarkan seorang pekerja yang dapat diandalkan yaitu: sikap mengikuti petunjuk, sikap mematuhi peraturan, dapat diandalkan, dapat dipercaya, berhati-hati, jujur, an tepat waktu.

\section{B. Faktor-Faktor Yang Memengaruhi Etos Kerja \\ Adapun faktor-faktor yang} memengaruhi etos kerja seseorang adalah sebagai berikut, faktor internal oleh Boatwright \& Slate (dalam Kusnan, 2004) meliputi:

\section{Faktor Usia,}

Pekerja yang berusia di bawah 30 tahun memiliki etos kerja lebih tinggi daripada pekerja yang berusia di atas 30 tahun.

2. Faktor jenis kelamin,

Wanita memiliki etos kerja yang lebih tinggi dari pada pria;

3. Faktor latar belakang pendidikan,

Etos kerja tertiggi dimiliki oleh pekerja dengan latar belakang pendidikan S1 dan terendah dimiliki oleh pekerja dengan latar belakang pendidikan SMU;

4. Faktor lama bekerja,

Pekerja yang sudah bekerja selama 12 tahun memiliki etos kerja yang lebih tinggi daripada yang bekerja di bawah 1 tahun. Semakin lama individu bekerja, semakin tinggilah kemungkinan individu untuk memperoleh kesempatan untuk mengembangkan dan menggunakan kapasitasnya dan memperoleh peluang untuk pertumbuhan dan mendapatkan jaminan;

5. Faktor agama dan keyakinan,

Agama merupakan suatu sistem nilai. Sistem nilai ini akan mempengaruhi atau menentukan pola hidup para penganutnya. Cara berpikir, bersikap dan bertindak seseorang pastilah diwarnai oleh ajaran agama yang dianutnya jika orang tersebut sungguh-sungguh dalam kehidupan beragama. Ajaran agama mengandung nilai-nilai yang dapat memacu etos kerja seseorang. Menurut Max Weber (dalam Rosmiani,1996) bahwa doktrin predestinasi dalam protestanisme mampu melahirkan etos bepikir rasional, berdisplin tinggi, bekerja tekun sistematik, berorientasi suskes (material), tidak mengumbar kesenangan atau hemat, bersahaja (asketik), menabung atau berinvestasi;

6. Faktor motivasi

Menurut McClelland (dalam Uno, 2011: 9) bahwa A motiveis the redintegration by a cue of a change in an affective situation, yang berarti motivasi merupakan implikasi dari hasil pertimbangan yang telah dipelajari (redintegration) dengan ditandai suatu perubahan pada situasi afektif. Sumber utama dari munculnya mitivasi adalah ransangan (stimulasi) perbedaan situasi sekarang dengan situasi yang diharapkan, sehingga tanda perubahan tersebut tampak pada adanya perbedaan afektif saat muncunya motif dan saat usaha pencapaian yang diharapkan. McClelland (dalam fakih, 2009) mengatakan bahwa faktor internal yakni nilai-nilai dan motivasi yang lebih condong mendoron manusia mengeksploitasi peluang, meraih kesempatan, bekerja secara baik merubah nasib dan membentuk nasib sendiri. Dengan demikian stimulasi dan motivasi seseorang menjadi salah 
satu variabel pembentuk etos kerja seseorang.

Novliadi 2009 mengatakan bahwa selain faktor-faktor internal di atas, terdapat pula faktor eksternal yang memengaruhi etos kerja yaitu:

\section{Faktor budaya}

Masyarakat yang memiliki sistem budaya maju akan memiliki etos kerja yang lebih tinggi daripada masyarakat yang memiliki sistem budaya tidak maju;

\section{Faktor sosial politik}

Etos kerja yang dimiliki suatu masyarakat sangat tergantung kepada ada tidaknya struktur politik yang mendorng masyarakat untuk bekerja keras dan dapat menikmati hasil kerja keras mereka dengan penuh

3. Faktor kondisi lingkungan geografis Lingkungan alam yang mendukung, mempengaruhi manusia yang ada di dalamnya melakukan usaha untuk dapat mengelola dan mengambil manfaat, dan bahkan dapat mengundang pendatang untuk turut mencari penghidupan di lingkungan tersebut. Kondisi lingkungan inilah yang akan mempengaruhi bagaimana persepsi seseorang terhadap kualitas kehidupan bekerjanya

4. Faktor struktur ekonomi

Tinggi rendahnya etos kerja yang dimiliki masyarakat, dipengaruhi oleh ada atau tidaknya struktur ekonomi yang mampu memberikan insentif bagi anggota masyarakat untuk bekerja keras dan mennikmati hasil kerja keras mereka dengan penuh.

Dengan demikian, etos kerja individu sangat erat dengan kepribadian, tradisi, adat kebiasaan, rumusan akal, keyakinan, orientasi diri dan lain sebagainya. Manusia dicptakan dengan berbagai kelengkapan subjektif dan objektif untuk bekerja serta dianugerahkan akal pikiran, pedoman dan petunjuk hidup yang lengkap dalam bekerja supaya manusia mampu memenuhi kebutuhan hidup.

Dalam teori kebutuhan Maslow (dalam Uno, 2011: 41) membagi lima (5) tingkatan kebutuhan manusia (dari terendah ke tertinggi) yaitu :
1. Kebutuhan fisiologis yakni kebutuhan makanan, pakaian, udara, perumahan dan lain sebagainya;

2. Kebutuhan rasa aman yakni kebutuhan akan keselamatan termasuk aman dari ancaman fisik atau kehilangan serta merasa terjamin;

3. Kebutuhan akan cinta kasih atau kebutuhan sosial yakni dalam kaitannya dengan pekerjaan terkait dengan kebutuhan mendapatkan uang untuk memelihara gaya hidup dasar;

4. Kebutuhan akan penghargaan yakni menyangkut kebutuhan percaya diri, harga diri dan pengakuan orang lain;

5. Kebutuhan aktualisasi diri yakni berkaitan dengan keinginan pemenuhan diri.

\section{Kinerja Dan Hubungannya Dengan Etos Kerja}

Malayu S.P. Hasibuan (2011:34) mengemukakan bahwa kinerja adalah suatu hasil kerja yang dicapai seseorang dalam melaksanakan tugas tugas yang dibebankan kepadanya yang didasarkan atas kecakapan, pengalaman, dan kesungguhan serta waktu. Menurut Ambar Teguh Sulistiyani (2003:223) dalam Santoso (2012) Kinerja seseorang merupakan kombinasi dari kemampuan, usaha dan kesempatan yang dapat dinilai dari hasil kerjanya. Kemudian menurut Yusniar Lubis, Bambang Hermanto dan Emron Edison (2019:26) kinerja adalah hasil dari sebuah proses yang mengacu dan diukur selama periode tertentu berdasarkan ketentuan, standar atau kesempatan yang telah ditetapkan sebelumnya.

Berdasarkan beberapa beberapa devinisi tersebut di atas, penulis menarik kesimpulan bahwa kinerja adalah kemampuan individu dalam melaksanakan tugas dan tanggungjawabnya sehingga dapat mencapai prestasi kerja.

Menurut Robert L. Mathis dan john H. Jakson (2001:82) dalam Sinaga (2013) faktor-faktor yang memengaruhi kinerja individu yaitu:

1. Kemampuan mereka

2. Motivasi

3. Dukungan yang diterima 
4. Keberadaan pekerjaan yang mereka lakukan dan

5. Hubungan mereka dengan organisasi.

\section{METODE}

Penelitian ini bersifat analitik desktiktif
yang akan menganalisis kemudian mendeskripsikan berbagai kompleksitas etos kerja penerima bantuan dana bergulir PNPM Mandiri. Adapun fokus penelitian ini adalah etos kerja penerima bantuan dana bergulir PNPM Mandiri, faktor-faktor yang mempengaruhi etos kerja dan penerapan program kerja. Dalam penelitian ini menggunakan data primer diperoleh melalui proses wawancara dari pihak yang berkaitan dengan masalah penelitian yakni tim pelaksana program dan anggota KSM, sedangkan data sekunder diperoleh dari Kelurahan, kantor Badan Pusat Statistik, kantor wilayah VIII PNPM Mandiri Perkotaan Korkot 3 dan lembaga keswadayaan masyarakat. Teknik dan pengumpulan data berupa wawancara mendalam dan dokumentasi. Teknik analisis data yang digunakan dalam penelitian ini dimulai dari tahapan-tahapan reduksi data, display data, dan verifikasi data. Reduksi dilakukan denganmerangkum semua data yang terkumpul. Display data akan dilakukan melaluimenyajikan data dalam bentuk uraian dan hubungan antar kategori. Demikian pula tahapan verifikasi data akan dilakukan dengan membandingkan data yang dikumpulkan berdasarkan perbedaan informan dan berdasarkan perbedaan konteks.

\section{HASIL DAN PEMBAHASAN}

\section{Hasil}

1. Penyebab penerima bantuan dana bergulir PNPM Mandiri Kelurahan Latuppa memiliki etos kerja tinggi

Hasil wawancara peneliti dan beberapa informan dan anggota KSM penerima bantuan dana bergulir PNPM Mandiri keluraha Latuppa (yakni: KSM Melatih, KSM Cempaka, KSM Kayu Asik, KSM Merpati, dan KSM Mekar) yang menjadi sampel penelitian dan sebagai informan dalam penelitian ini terkait dengan penyebab penerima bantuan dana bergulir PNPM mandiri. Berdasarkan beberapa hasil wawancara penulis menemukan bahwa penerima bantuan dana bergulir PNPM mandiri kelurahan Latuppa memiliki etos kerja tinggi karena:

a. Adanya keahlian interpersonal yang dimiliki oleh penerima bantuan dana bergulir PNPM mandiri Kelurahan Latuppa yaknikebiasaan danperilaku yang sopan, bersahabat, gembira, penuh perhatian, menyenangkan, suka kerja sama, suka menolong, tekun, sabar, kerja keras, dan rendah hati dalam bekerja atau menjalankan usaha;

b. Adanya inisiatif tinggi yang dimiliki oleh penerimah bantuan dana bergulir PNPM mandiri Kelurahan Latuppa seperti sikap cerdik, banyak ide, produktif, antusias, mandiri, efektif, efisien, mampu beradaptasi, gigih, dan berinisiatif;

c. Adanya nilai - nilai kehandalan yang dianut oleh penerima bantuan dana bergulir PNPM mandiri Kelurahan Latuppa seperti nilai-nilai kejujuran, kepercayaan dan berhati - hati dalam bekerja;

d. Adanya pemberdayaan dan pembelajaran yang telah dialami oleh penerima bantuan dana bergulir PNPM mandiri Kelurahan latuppa.

Namum keempat penyebab penerima bantuan dana bergulir PNPM mandiri memiliki etos kerja tinggi tersebut diatas, tidak terlepas dari faktor internal dan faktor eksternal yang mempengaruhi etos kerja seseorang yakni sebagai berikut:

1. Faktor internal, meliputi: faktor jenis kelamin, faktor agama atau keyakinan, faktor lama bekerja, dan faktor motifasi;

2. Faktor eksternal, meliputi: faktor budaya, faktor kondisi lingkungan geografis, faktor struktur ekonomi;

3. Selain faktor internal dan faktor eksternal tersebut, peneliti juga menemukan dilapangan bahwa penerima bantuan dana bergulir PNPM mandiri kelurahan Latuppa memiliki etos kerja tinggi karena dipengaruhi oleh faktor kebutuahn hidup, faktor kewajiban dan tanggung jawab, dan faktor kelompok.

\section{Penerapan Program kerja dan Stimulasi Etos Kerja}


Penerapan program kerja bantuan dana bergulir PNPM mandiri yakni menggunakan sistem pendekatan partisipasi dengan konsep pemberdayaan dan pembelajaran kritis masyarakat.

Dari hasil wawancara, memberikan gambaran bahwa substansi pokok dalam penerapan program kerja bantuan dana bergulir PNPM Mandiri adalah penyadaran masyarakat miskin tentang pentingnya penerapan nilai-nilai moral manusia dan nilai-nilai universal kemasyarakatan dalam bekerja atau menjalankan usaha, peran masyarakat miskin penerima bantuan dana bergulir PNPM Mandiri dalam program bantuan dana bergulir PNPM Mandiri bukan hanya sebagai objek program tetapi juga sebagai subjek program. Artinya masyarakat miskin penerima bantuan dana bergulir PNPM mandiri terlibat langsung dalam penerapan program.

Beberapa hasil wawacara dan penelitian, memberi gambaran bahwa penerapan program kerja bantuan dana bergulir PNPM mandiri melalui pendekatan partisipatif dengan konsep pemberdayaan dan pembelajaran yang kritis masyarakat telah memberikan pencerahan dan pembuka paradigma baru masyarakat miskin penerima bantuan dana bergulir PNPM Mandiri kelurahan latuppa, sehingga memicu etos kerja mereka untuk memanfaatkan lingkungan tempat tinggal mereka dan meragamkan usaha produktif mereka demi meningkatkan pendapatan keluarga guna mencapai hidup sejantera

Dengan deikian, proses penerapan program kerja yang menstimulasi etos kerja bantuan dana bergulir PNPM Mandiri sebagai berikut:

1. Revitalisasi dan pembelajaran nilai-nilai moral manusia atau nilai-nilai universal kemanusiaan (seperti; dapat dipercaya, kejujuran, keikhlasan, kesetaraan, keadilan, dan kebersamaan) dan nilai-nilai kemasyarakatan (seperti; demokrasi, partisipasi, transparansi, akuntabilitas, dan desentralisasi) dengan menggunakan prinsip saling membantu atau menolong yang lemah, saling peduli, saling bertanggung jawab, kekeluargaan, dan gotong royong;
2. Membangun kesadaran kritis masyarakat penerima bantuan dana bergulir PNPM mandiri untuk ikut berpartisipasi secara langsung dalam pelaksanaan program kerja bantuan dana bergulir PNPM Mandiri yakni mulai dari proses identifikasi masalah dan kebutuhan, perencanaan, pelaksanaan, pengawasan sampai pada evaluasi program;

3. Pembelajaran untuk berhimpun atau berkelompok dalam menghadapi dan menyelesaikan masalah bersama dengan cara membentuk lembaga keswadayaan masyarakat seperti; membentuk Badan Keswadayaan Masyarakat/ Lembaga Keswadayaan Masyarakat (BKM/LKM), Unit Pengelolah Keuangan (UPK), Unit Pengelolah Lingkungan (UPL), Unit Pengelolah Sosial (UPS), dan Kelompok Swadaya Masyarakat (KSM).

\section{Pembahasan}

1. Faktor-faktor yang mepengaruhi penerimah bantuan dana bergulir PNPM Mandiri Kelurahan latuppa Kecamatan Mungkajang Kota palopo memiliki etos kerja tinggi

Penyebab penerimah bantuan dana bergulir PNPM mandiri memiliki etos kerja tinggi tersebut di atas, tidak terlepas dari faktor internal dan faktor eksternal yang mempengaruhi etos kerja seseorang yakni sebagai berikut:

1. Faktor internal

a. Faktor jenis kelamin, sebagaimana hasil temuan penulis yang telah diuraikan di atas, bahwa pada tahun 2012 menunjukkan dari 308 orang menerimah bantuan dana bergulir PNPM Mandiri kelurahan Latuppa yang tergabung dalam 55 KSM terdapat $210 \quad$ orang perempuan dan laki-laki 98 orang. Berarti penerima bantuan dana bergulir PNPM mandiri kelurahan latuppa kebanyakan berjenis kelamin perempuan dan sangat besar respon perempuan miskin Kelurahan Latuppa 
memanfaatkan bantuan dana bergulir PNPM mandiri. Realitas ini memberi gambaran bahwa pada dasarnya perempuan miskin kelurahan Latuppa berpresepsi "bekerja bukan hanya tugas laki-laki akan tetapi perempuan juga bertanggung jawab membantu suami bekerja demi peningkatan pendepatan keluarga"

b. Faktor agama atau keyakinan, sebagaimana temuan penulis yang telah diuraikan diatas, bahwa semua anggota KSM penerima bantuan dana bergulir PNPM Mandiri kelurahan Latuppa beragama islam dan memiliki keyakinan "bekerja merupakan bagian ibadah setiap manusia" ini berarti bahwa penerima bantuan dana bergulir PNPM Mandiri kelurahan latuppa mengaplikasikan nilai-nilai ajaran agama islam dalam kehidupan sehari-harinya.

c. Faktor lama bekerja, sebagai temuan penulis, bahwa penerima bantuan dana bergulir PNPM mandiri kelurahan Latuppa memiliki pengalaman kerja yang cukup lama yakni sekitar 10-15 tahun karena rata-rata usia mareka di atas 30 tahun. Walau pengalaman kerja mereka hanya dibidang sektor informal seperti: pengalaman kerja sebagai pedagang/pengecer, penjual makanan dan minuman ringan, tukang kayu, tukang ojek, dan kebanyakan tukang kebun atau buruh tani, akan tetapi pengalamanpengalaman bekerja tersebut telah banyak memberikan pembelajaran bahwa untuk memperoleh hasil yang maksimal dalam berusaha atau bekerja diperlukan ketekunan, kesabaran, kepercayaan, kejujuran, dan usaha sungguh-sunggu.

d. Faktor motifasi, sebagaimana temuan penulis dari beberapa hasil wawancara dengan penerima bantuan dana bergulir PNPM Mandiri kelurahan Latuppa. Bahwa penerima bantuan dana ebrgulir PNPM Mandiri memiliki etos kerja yang tinggi karena termotifasi untuk memenuhi kebutuhan hidup dan pemberdayaan dan pembelajaran yang mereka terima dari tim pelaksana program bantuan dana bergulir PNPM mandiri, juga memotifasi mereka untuk lebih bersemangat, lebih kreatif, lebih berhati-hati, jujur, tepat waktu dan lebih jelih dalam meraih peluang berusaha. Ini berarti setiap indifidu memiliki unsur internal, dimana unsur internal tersebut turut berperan dalam aktifitas dirinya sehari-hari, dan salah satu kondisi internal tersebut adalah "motifasi".

2. Faktor Eksternal

a. Faktor budaya, sistem nilai budaya merupakan suatu rangkaian darikonsepsikonsepsi abstrak yang hidup di alam fikiran masyarakat mengenai apa yang dianggap penting atau berharga atau apa yang dianggap remeh dan tak berharga dalam hidup. Ini berarti setiap masyarakat menganut sistem nilai budaya yang berbeda termasuk budaya dalam bekerja, begitupula halnya dengan masyarakat Keluraha Latuppa mereka memiliki budayabudaya tertentu dalam hidupnya. 
b. Faktor kondisi lingkungan geografis, keberhasilan pembangunan ekonomi nasional sangat ditentukan oleh beberapa faktor meliputi: ketersediaan sumber daya alam, sumber daya manusia atau skill, sumber daya teknologi, sumber daya informasi, situasi politik, kebijakan-kebijakan pemerintah dan lain sebagainya. Kelurahan latuppa merupakan salah satu kelurahan yang ada di kota madya palopo yang terletak di wilayahnya berada di lereng perbukitan dan pegunungan. Walaupun secara administrasi kelurahan Latuppa masuk dalam wilayah perkotaan, namun jika dilihat dari segi letak dan kondisi wilayah maka kelurahan Latuppa dikategorikan pedesaan. Karena itulah mata pencaharian utama masyarakat kelurahan Latuppa adalah perkebunan dan ini berarti masyarakat kelurahan sangat tergantung dengan potensi alam lingkungan geografis. Kelurahan latuppa memiliki kondisi lingkungan geografis yang sangat potensial dari segi pengembangan ekonomi terutama untuk pengembangan perkebunan dan wisata. Karena kelurahan Latuppa terletak diantara deretan perbukitan yang memiliki tanah subur sehingga cocok untuk berbagai jenis tanaman perkebunan terutama tanaman coklat, cengkeh, nilam, buah-buahan dan sayur mayur. Aset wisata kelurahan Latuppa adalah wisata air, dimana disepanjang jalan poros sisi sebelah kiri kelurahan Latuppa terdapat aliran sungai yang jernih dan berbatu serta dua buah air terjun. Sehingga setiap hari libur kelurahan Latuppa menjadi tujuan wisata masyarakat dari berbagai daerah. Apalagi didukung akses jalan ke kelurahan Latuppa yang bagus dengan jarak yang cukup dekat yakni hanya sekitar $8 \mathrm{~km}$ dari pusat kota. Dengan konsidi lingkungan geografis tersebut, sangat mendukung pengembangan ekonomi dan peningkatan etos kerja para penerima bantuan dana bergulir PNPM Mandiri untuk mengambil manfaat atau peluang memulai usaha (bisnis) atau mengembangkan usahanya terutama dalam usaha perkebunan, usaha perdagangan (jual beli makanan dan minuman) dan usaha industri rumah tangga.

c. Faktor struktur ekonomi, negara maju dan negara yang mampu mencapai tingkat kesejahteraan yang tinggi tidak lepas dari unsur keberhasilan pemerintah dalam menata struktur ekonominya. Mill (dalam Jhingan, 2004) dalam teorinya mengenai Pembangunan ekonomi bahwa pembangunan ekonomi sebagai fungsi dari tanah, tenaga kerja dan modal. Mill juga mengatakan bahwa peningkatan kesejahteraan hanya mungkin tercapai bila tanah dan modal mampu meningkatkan produksi dibandingkan dengan angkatan kerja serta struktur ekonomi dan pemerintah mendukung. Oleh karena itu, campuran tangan pemerintah Mill pandang perlu terutama dalam hal perbaikan redistribusi, 
perbaikan sarana produksi dan ketersediaan modal. Program bantuan dana bergulir PNPM Mandiri merupakan salah satu program sebagai dukungan dan wujud campur tangan pemerintah Indonesia dalam hal pengembangan ekonomi terutama untuk pementasan kemiskinan di Indonesia. Orientasi kebijakan program bantuan dana bergulir PNPM mandiri adalah membantu masyarakat miskin yang tidak produktif dan tidak mandiri menjadi masyarakat produktif dan mandiri dengan cara memberikan dana stimulan kepada masyarakat miskin sebagai modal awal untuk memulai suatu usaha atau modal pengembangan usaha yang sudah memilikinya. Agar penerapan program bantuan dana bergulir PNPM mandiri dapat efektif dan sukses maka pemerintah menggunakan pendekatan partisipatif dengan konsep pemberdayaan kritis masyarakat.

2. Proses Penerapan Program kerja bantuan Dana bergulir PNPM Mandiri yang Menstimulasi Etos Kerja Penerimah Bantuan Dana Bergulir PNPM Mandiri

Dari hasil penelitian, memberi gambaran bahwa etos kerja seseorang tidak lepas dari beberapa aspek yang melekat pada diri manusia yakni aspek interpersonal, inisiatif dan kehandalan. Aspek-aspek etos kerja yang melekat pada diri penerima bantuan dana bergulir PNPM Mandiri kelurahan Latuppa semakin berkembang dan meningkat setelah mengalami berbagai proses pemberdayaan dan pembelajaran kritis dari tim pelaksana program bantuan dana bergulir PNPM Mandiri. Etos kerja seseorang juga sangat terkait erat dengan faktor internal dan faktor eksternal dalam kehidupan manusia. Etos kerja seseorang bersifat fleksibel maksudnya etos ekrja seseorang dapat mengalami peningkatan dan dapat mengalami penurunan, tergantung dinamika hidup yang manusia alami dalam kehidupannya.

Sebelum adanya program bantuan dana bergulir PNPM Mandiri, masyarakat miskin kelurahan latuppa hanya menggantungkan hidupnya dari hasil perkebunan saja. Aktifitas keseharian bekerja mereka hanya pada satu jenis pekerjaan. Selain itu masyarakat miskin kelurahan Latuppa kurang memanfaatkan potensi lingkungan tempat tinggal mereka. Semua ini dikarenakan kurangnya pemahaman dan pengetahuan mereka tentang bagaimana menggali dan mengembangkan potensi diri dan potensi lingkungan tinggal mereka. Serta masyarakat miskin keluarahan Latuppa tidak memiliki daya untuk meraih peluang-peluang usaha disebabkan karena ketidaktersediaan modal usaha.

Setelah program bantuan dana bergulir PNPM Mandiri masuk ke kelurahan Latuppa dan tim pelaksana program melakukan berbagai proses pemberdayaan dan pembelajaran kritis masyarakat, maka stimulasistimulasi yang telah dilakukan oleh tim pelaksana program bantuan dana bergulir PNPM Mandiri Kelurahan Latuppa pelan-pelan membuat terjadinya pergeseran dan perkembangan paradigma dan aktifitas hidup masyarakat miskin Kelurahan Latuppa.

\section{SIMPULAN DAN SARAN}

\section{Kesimpulan}

Berdasarkan hasil penelitian penulis, yang telah diuraikan dalam Bab hasil penelitian dan pembahasan, maka dapat ditarik kesimpulan bahwa bantuan dana bergulir PNPM Mandiri Kelurahan Latuppa 
Kecamatan mungkajang Kota Palopo memiliki etos kerja tinggi karena adanya keahlian interpersonal yang dimiliki oleh penerima bantuan dana bergulir PNPM Mandiri kelurahan latuppa kecamatan seperti kebiasaan dan perilaku yang sopan, bersahabat, gembira, penuh perhatian, menyenangkan, suka bekerja sama, suka menolong, tekun, sabar, kerja keras, dan rendah hati bekerja atau menjalankan usaha; adanya inisiatif tinggi yang dimiliki oleh penerima bantuan dana bergulir PNPM Mandiri kelurahan latuppa seperti cerdik, Banyak ide, produktif, antusias, Mandiri, efektif, mampu beradaptasi dan gigih dalam bekerja atau menjalankan usaha; adanya nilainilai kehandalan yang dianut oleh penerima bantuan dana bergulir PNPM Mandiri kelurahan latuppa seperti menjunjung tinggi nilai-nilai kejujuran, nilai-nilai kepercayaan dan berhati-hati dalam bekerja menjalankan usaha; dan adanya pemberdayaan dan pembelajaran yang telah diterima oleh penerima bantuan dana bergulir PNPM Mandiri Kelurahan latuppa, yakni pembelajaran tentang mengidentifikasi kebutuhan sendiri, mengidentifikasi masalah yang dihadapi mencari jalan keluar dari masalah tersebut, pembelajaran tentang pengembangan potensi diri dan potensi lingkungan tempat tinggal serta pembelajaran tentang pentingnya penerapan nilai-nilai moral atau nilai-nilai universal kemanusiaan dan nilai-nilai universal kemasyarakatan dalam hidup Sehingga masyarakat miskin tersebut memiliki kemampuan percakapan, kualitas dan motivasi dalam bekerja atau berusaha, yang pada akhirnya akan melahirkan keyakinan, pandangan, sikap yang menghargai kerja sebagai suatu berharga dan bernilai bagi kehidupannya.

Selain hal tersebut di atas, penerimaan bantuan dana bergulir PNPM Mandiri Kelurahan Latuppa memiliki etos kerja tinggi karena juga dipengaruhi oleh faktor internal (meliputi; faktor jenis kelamin, faktor agama atau keyakinan, faktor lama bekerja, faktor motivasi), faktor eksternal (meliputi; faktor budaya, faktor kondisi lingkungan geografis dan faktor struktur ekonomi) dan beberapa faktor lain yang peneliti temukan di lapangan seperti: faktor kebutuhan, faktor kewajiban dan tanggung jawab serta faktor kelompok.
Proses penerapan program kerja yang menstimulasi etos kerja penerima bantuan dana bergulir PNPM Mandiri adalah revitalisasi dan pembelajaran nilai-nilai moral manusia atau nilai-nilai universal kemanusiaan (seperti: dapat dipercaya, kejujuran, keikhlasan, kesetaraan, dan kebersamaan) dan nilai-nilai kemasyarakatan (seperti: demokrasi, partisipasi, transparansi, akuntabilitas, dan desentralisasi) dengan menggunakan prinsip saling membantu atau menolong yang lemah, saling peduli, saling bertanggung, jawab, kekeluargaan dan gotong royong; membangun kesadaran kritis masyarakat untuk ikut berpartisipasi secara langsung dalam pelaksanaan program kerja bantuan dana bergulir PNPM Mandiri yakni mulai dari proses identifikasi masalah dan kebutuhan, perencanaan, pelaksanaan, pengawasan sampai pada evaluasi program sehingga masyarakat miskin tersebut mampu mengidentifikasi kebutuhannya sendiri, mengidentifikasi masalah-masalah yang dihadapi, mampu mengatasi masalah tersebut serta mampu mengembangkan potensi dirinya; dan pembelajaran untuk berhimpun atau berkelompok dalam menghadapi, mengelola dan menyelesaikan masalah secara bersama dengan membentuk lembaga kepemimpinan atau keswadayaan masyarakat seperti: membentuk BKM/LKM,IPK, UPS, dan KSM.

\section{Saran}

Saran dari penulis sebagai berikut.

1. Hendaklah tim pelaksana program bantuan dana PNPM Mandiri lebih sering berkoordinasi dengan masyarakat penerima bantuan dana bergulir PNPM Mandiri agar menerima bantuan dana bergulir tersebut semakin berdaya terutama dalam hal pengembangan usaha

2. Hendak pemerintah setempat dan tim pelaksana program bantuan dana bergulir PNPM Mandiri sering melakukan kegiatan pelatihan pelatihan yang dapat meningkatkan skill atau keterampilan masyarakat dalam mengelola kelembagaan-kelembagaan kemasyarakatan yang yang suka terbentuk 
DAFTAR RUJUKAN

Fakih, Mansour. 2009. Runtuhnya Teori Pembangunan dan Globalisasi, Yogyakarta: Insist Press.

Hasibuan, Malayu SP. (2011). Manajemen Sumber Daya Manusia. Jakarta: Bumi Aksara

Jhingan, M.L. 2004. Ekonomi Pembangunan dan Perencanaan, Jakarta: Raja Grafindo Persada.

Kusnan, Ahmad (2004); Analisis Sikap Iklim Organisasi, Etos Kerja Dan Disiplin Kerja Dalam Menentukan Efektifitas Kinerja Organisasi di Garnizun Tetap III Surabaya; Laporan Penelitian; http://www.damandiri.or.id/ index.php [online : Monday, October 16, 2006, 6:03:24 PM]

Lubis, Y., Hermanto, B., \& Edison, E. 2019. Manajemen Dan Riset Sumber Daya Manusia, Bandung: Alfabeta.

Novliadi, F., Psi, S., \& Si, M. (2009). Hubungan Antara Organization-Based Self Esteem Dengan Etos Kerja.

Prabowo, O. S. (2009). Analisis Pengaruh Human Relation, Kondisi Fisik Lingkungan Kerja, dan Leadership Terhadap Etos Kerja Karyawan Kantor Pendapatan Daerah Di Pati (Doctoral dissertation, Universitas Muhammadiyah Surakarta).

Sinaga, T., \& Sinambela, M. (2013). Pengaruh stres kerja terhadap motivasi dan kinerja auditor pada kantor akuntan publik di kota Medan. Universitas Tarumanagara Journal of Accounting, 17(1).

Sinamo, Jansen., (2005); Delapan Etos Kerja Profesional; Navigator Anda Menuju Sukses; Grafika Mardi Yuana, Bogor.

Santoso, B., \& Riyardi, A. (2012). rotasi, mutasi dan promosi karyawan di kantor pelayanan pajak Pratama Klaten.

Uno, Hamzah B. 2011. Teori Motivasi Dan Pengukurannya, Jakarta: Bumi Aksara.

\section{Editor In Chief}

Rosmini Maru

rosminimaru@unm.ac.id

\section{Publisher}

\section{Geography Education, Postgraduate}

Program, Universitas Negeri Makassar

$\mathrm{Jl}$. Bonto Langkasa Gunungsari Baru

Makassar, 90222 Kampus PPs UNM

Makassar Gedung AB ruang 01, Indonesia

Email : ugj@unm.ac.id

Info Berlangganan Jurnal

085299874629 / Ihsan 